\title{
Czynniki i skutki rozwoju przemysłu motoryzacyjnego na terenie województwa śląskiego
}

Obszar województwa śląskiego, ze względu na ilość funkcjonujących tu nowych zakładów dostarczających podzespoły samochodowe, zlokalizowanie w Gliwicach fabryki samochodów Opla, jak i rozwój dawnej FSM w Tychach i Bielsku-Białej po przejęciu jej przez Fiata, zaczęto nazywać zagłębiem motoryzacyjnym. Oprócz wymienionych fabryk samochodów działa tu wiele wytwórni części i podzespołów, w większości renomowanych marek światowych, wśród których najważniejszymi są: amerykański Delphi i TRW, japoński Isuzu, włoskie, zależne od Fiata - Magneti Marelli i Teksid oraz Manuli Rubber, a także niemieckie koncerny Mahle i HP-Pelzer. Według danych Polskiej Agencji Inwestycji Zagranicznych firmy motoryzacyjne zainwestowały w tym regionie blisko 4 mld USD. Znaczna część inwestorów wybrała tereny należące do Katowickiej Specjalnej Strefy Ekonomicznej, gdzie szczególnym zainteresowaniem cieszyły się obszary podstrefy tyskiej i gliwickiej.

Poznanie przyczyn tak intensywnego rozwoju przemysłu motoryzacyjnego na obszarze województwa śląskiego, uznawanego w teoriach lokalizacji za przemysł o lokalizacji swobodnej (m.in. Hurley 1959, Riley 1973) wydaje się być istotnym zagadnieniem badawczym z punktu widzenia rozwoju regionalnego. Znane są ogólne czynniki decydujące o lokalizacji przedsiębiorstw branży motoryzacyjnej. Wielu autorów współczesnych opracowań interesuje rozwój tego przemysłu szczególnie na obszarach państw, do których następuje relokacja tego typu zakładów z krajów o najwyższym poziomie rozwoju (m.in. Sadler 1998). Do takich obszarów niewątpliwie należy cała Europa Środkowa, a w szczególności Słowacja, Czechy i południowa Polska.

Innym istotnym aspektem badawczym jest wielkość i rodzaj powstających oddziaływań regionalnych i lokalnych wynikających z szybkiego rozwoju przemysłu motoryzacyjnego. Określenie jego zasięgu pozwoli wskazać miejsca kumulowania się nowych korzyści rozwojowych, co jest ważne z perspektywy rozwoju tego obszaru. Przemysł motoryzacyjny ma tu szczególne znaczenie, gdyż jest on uznawany za branżę, która obecnie przynosi najwięcej korzyści dla gospodarki lokalnej i regionalnej, ze względu na najwyższe wskaźniki efektów mnożnikowych. Wynika to przede wszystkim z najbardziej rozbudowanej sieci powiązań, spowodowanej dużym wolumenem produkcji i złożonością wyrobu jakim jest samochód.

Od ponad dwudziestu lat widoczny jest wśród geografów przemysłu wzrost zainteresowań badawczych relacjami pomiędzy kształtowaniem się sieci firm w regionie a wpływem na jego rozwój (Hayter i Watts 1983, Scott i Storper 1987, Scott 1988, Dicken, Forsgreen i Malmberg 1994, Dicken i Malmberg 2001). Badania te skupiają się na procesach kształ- 
towania relacji wewnątrz sieci firm, zwłaszcza w kontekście tworzenia przez nie dzielnic i aglomeracji przemysłowych. Spośród szerokich opracowań dotyczących czynników lokalizacji należy wymienić opracowanie H.D. Watts (1987). W ostatnim czasie powstało także kilka opracowań dotyczących powiązań przedsiębiorstw w skali regionalnej i lokalnej (m.in. Stryjakiewicz 2004; Domański, Gwosdz 2005), określanych terminem embeddedness. Odczuwalny jest natomiast niedostatek badań, które w sposób dynamiczny pokazywałyby procesy rozwoju i wielkość oddziaływań tego przemysłu w skali wewnątrzregionalnej, m.in. na obszarze województwa śląskiego, którego struktura gospodarcza była dotychczas zdominowana przez tzw. przemysł ciężki.

\section{ROZWÓJ PRZEMYSŁU MOTORYZACYJNEGO W WOJEWÓDZTWIE ŚLĄSKIM}

Rozwój przemysłu motoryzacyjnego na obszarze należącym dziś do województwa śląskiego rozpoczął się stosunkowo późno. Pierwsze zakłady zaczęły specjalizować się w tej produkcji dopiero w drugiej połowie XX wieku. Przełomową inwestycją w tym zakresie było uruchomienie w Bielsku-Białej produkcji jednostek napędowych dla wytwarzanych w Fabryce Samochodów Osobowych na Żeraniu samochodów Syrena. Dalszy rozwój FSO, spowodowany zakupem licencji na produkcję modelu Fiat 125, spowodował przeniesienie produkowanej tam Syreny do Bielska-Białej. Od tego momentu na terenie województwa śląskiego były wytwarzane samochody osobowe.

Przejęcie władzy w Polsce po 1970 roku przez układ związany z wywodzącym się z tego terenu I Sekretarzem KC PZPR Edwardem Gierkiem spowodowało duże przyśpieszenie w rozwoju przemysłu na tym obszarze. Należy pamiętać, że w okresie PRL najważniejszym czynnikiem lokalizacji nowych inwestycji i rozwoju przemysłu były kwestie polityczne. Już w 1971 roku nastąpiło podpisanie umowy na zakup licencji na samochód Fiat 126, który miał być montowany w Tychach, a bielskie zakłady WSM miały być dostawca jednostek napędowych. Decyzja o powstaniu tej fabryki (FSM) wiązała się z szeregiem korzyści dla gospodarki regionalnej, gdyż spowodowała transfer nowoczesnych technologii do zakładów, które weszły w skład FSM, a także do ich kooperantów. Rozbudowa zakładów miała bardzo duże znaczenie dla dalszego rozwoju przemysłu samochodowego. Wiele zmodernizowanych fabryk, a także ta powstała od podstaw w Tychach, stanowi dzisiaj podstawę funkcjonowania największego producenta samochodów w kraju - Fiata Auto Poland.

Po przemianach gospodarczych przełomu lat osiemdziesiątych i dziewięćdziesiątych model centralnego zarządzania i związana z nim dominacja ekonomii politycznej ustapiła mechanizmom wolnego rynku. Wpłynęło to w oczywisty sposób na funkcjonowanie przedsiębiorstw. W dotychczas funkcjonującej gospodarce, jaka miała miejsce w całym bloku krajów socjalistycznych, zarówno własność jak i pełna kontrola zdecydowanej większości przedsiębiorstw należały do państwa. To ono decydowało o strukturze branżowej produkcji przemysłowej, asortymencie wyrobów oraz wolumenie produkcji w poszczególnych zakładach.

Nastawienie gospodarki na wielkość produkcji, jako najważniejszy czynnik rozwoju ekonomicznego krajów socjalistycznych, powodowało jednocześnie wysoką pracochłonność, materiałochłonność i energochłonność przemysłu. Rezultatem tego było wysokie zatrudnienie względem wielkości produkcji, czyli niska wydajność pracy. Dla zobrazowania 
skali tego zjawiska, zestawiono na wykresie (ryc. 1) wartość dodaną i zatrudnienie w przemyśle środków transportu wybranych krajów europejskich.

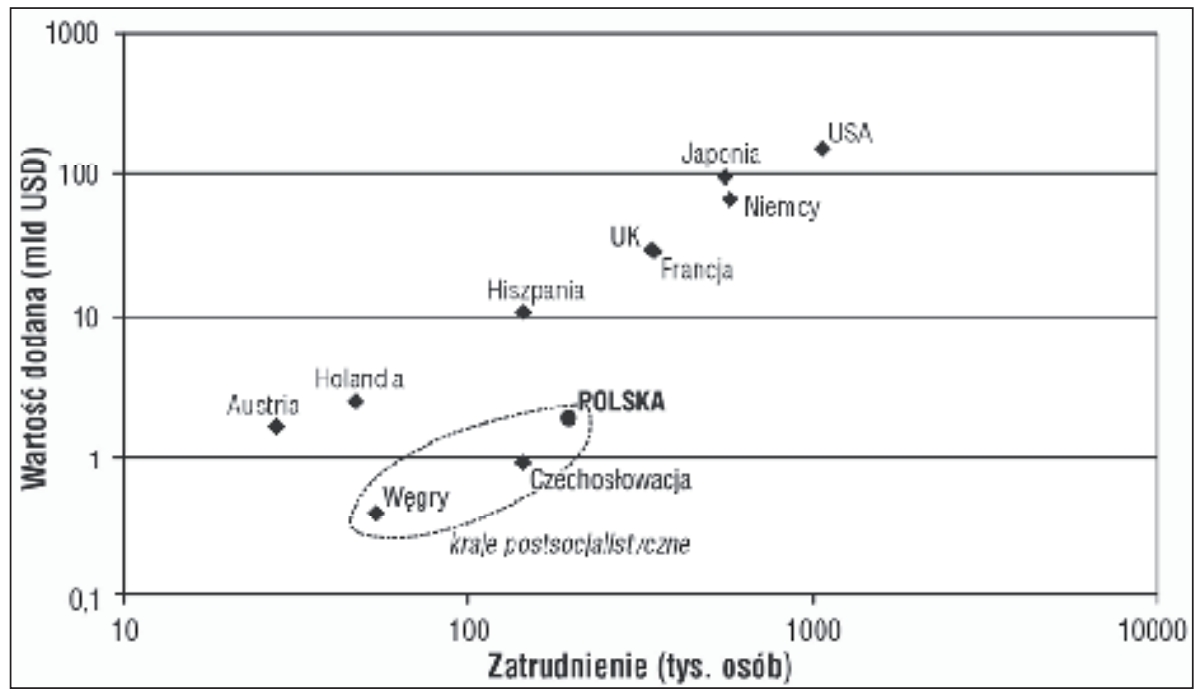

Ryc. 1. Wartość dodana i zatrudnienie w przemyśle środków transportu Polski na tle wybranych krajów Europy oraz Japonii i USA w 1990 roku

Źródło: Opracowanie własne na podst. danych Industrial Statistic Database 2001

Oprócz niskiej efektywności ekonomicznej produkcji w nowych warunkach ekonomicznych, otwarcie granic szybko ukazało zacofanie technologiczne wytwarzanych w Polsce samochodów. Utrzymanie się firm w nowych warunkach ekonomicznych wymagało wprowadzenia nowych modeli samochodów. To pociagało za sobą konieczność inwestycji w nowe linie technologiczne, nie tylko u producentów samochodów, ale także u ich dostawców. Kolejnym problemem było zapewnienie odpowiedniego poziomu sprzedaży poprzez znalezienie odbiorców na produkowane samochody.

Dalszy rozwój przemysłu motoryzacyjnego nie tylko na Śląsku, ale i w całym kraju wymagał z jednej strony przekształceń istniejących już tu zakładów, z drugiej - inwestycji w nowe fabryki. Na większą skalę wcześniejsze przemiany w tym przemyśle na terenie konurbacji śląskiej rozpoczęły się dzięki inwestycjom w już istniejące firmy. Przyczynami tego procesu była duża ilość zakładów rozbudowanych tu jeszcze od lat siedemdziesiątych, a także wdrożenie regulacji prawnych i działania na szczeblu rządowym, mające na celu sprywatyzowanie tych zakładów.

Największą rewolucję w branży w pierwszej połowie lat dziewięćdziesiątych stanowiła prywatyzacja grupy FSM. Od początku procesu prywatyzacji poszukiwano partnera, który mógłby się stać inwestorem strategicznym dla całego koncernu. Ostatecznie umowę prywatyzacyjną podpisano z Fiatem; na mocy tej umowy objął on $90 \%$ udziałów w trzech nowo utworzonych spółkach:

- produkującej samochody Fiat Auto Poland (FAP) w Tychach i Bielsku-Białej oraz zrzeszającej kilku ważnych dostawców komponentów, np. Zakłady FAP w Częstochowie i Bielsku-Białej Wapienicy, 
- Magneti Marelli Poland, która wytwarzała m.in. zestawy wskaźników i elementy oświetlenia na terenie Sosnowca,

- Teksid Poland, specjalizującej się w odlewach dla przemysłu motoryzacyjnego (zakłady w Skoczowie i Bielsku-Białej).

Poza wymienionymi podmiotami produkcyjnymi w ramach struktur FSM funkcjonowały także inne zakłady. Znalazły się one w nowo utworzonej spółce państwowej FSM Wytwórnia Wyrobów Różnych, która miała na celu ich dalszą prywatyzację. W grupie tych zakładów znalazły się:

- Zakłady Kuźnicze w Skoczowie i Ustroniu (w ramach FSM zakłady nr 3 i 4),

- Fabryka Rowerów Apollo w Czechowicach (wcześniej zakład nr 8),

- Bielska Fabryka Obrabiarek (wcześniej zakład nr 9).

Do struktur FSM WWR włączono także jednostki nieprodukcyjne w postaci mieszkań pracowniczych i domów wypoczynkowych.

Zmiany w polskiej części grupy Fiata rozpoczęto od ograniczenia niezależności poszczególnych jednostek dawnego FSM. W zakresie produkcji FAP postanowił skoncentrować się wyłącznie na asortymencie wytwarzanym dla potrzeb motoryzacji. Kolejnym etapem było stworzenie centralnego polskiego managementu, aby w miejsce celów wytyczonych sobie przez każdego z dyrektorów poszczególnych zakładów, pojawiły się cele wspólne. Objęcie zarządzania przez Fiata pozwoliło na swobodne decydowanie o wyborze dostawców. Niektórzy z dostawców nie rozumieli jeszcze reguł wolnego rynku. Kiedy w 1993 roku Fiat Auto Poland rozpoczynał swoją działalność, od polskich dostawców kupowano ponad połowę podzespołów. W 1998 roku firmy zlokalizowane w Polsce stanowiły już trzy czwarte wszystkich kooperantów.

Przez pierwsze trzy lata Fiat Auto Poland produkował dwa modele najmniejszych w Polsce samochodów - Fiata 126p i Cinquecento. W 1994 roku zaczęto montować inny mały samochód - Fiat Uno. Montaż szybko przekształcił się w pełny cykl technologiczny. Prowadzona od początku lat dziewięćdziesiątych restrukturyzacja i modernizacja zakładów Fiata umożliwiła we wrześniu 1996 roku otrzymanie Certyfikatu ISO 9001 świadczącego o najwyższym poziomie gwarancji jakościowych we wszystkich dziedzinach zarządzania przedsiębiorstwem. W 1997 roku w Zakładzie Karoserii w Bielsku-Białej uruchomiono produkcję Fiata Siena, a kilka miesięcy później pojawił się Fiat Palio Weekend. Rekordowy pod względem produkcji był rok 1999, w którym wyprodukowano ponad 340 tysięcy aut. W tej liczbie były też Punto, Bravo/Brava, Marea i Ducato - produkowane metodą montażu przemysłowego. Wiosną 1998 roku z linii produkcyjnych FAP spółki zjechał następca „Pięćsetki” - Seicento, który szybko stał się niekwestionowanym liderem w sprzedaży na rynku polskim i przebojem eksportowym. W 2000 roku postanowiono zaprzestać dalszego montażu samochodów na terenie Bielska-Białej, zostawiając tam zakład produkujący wyłącznie silniki i skrzynie biegów. W tym też roku zakończyła się produkcja Fiata 126. W 2004 roku w tyskim zakładzie Fiat Auto Poland spółka wprowadziła do produkcji Fiata Panda. Dzięki bardzo dużej popularności tego modelu tyski zakład osiągnął bardzo dobre wyniki ekonomiczne, umacniając się tym samym na pozycji lidera wśród wszystkich zakładów w grupie Fiata. Obecnie trwają prace nad wdrożeniem do produkcji kolejnego modelu małego samochodu, który zastąpi Fiata Seicento, a wspólnie z Fordem przygotowywana jest produkcja nowego najmniejszego Forda, następcy modelu Ka.

Pod koniec 1993 roku, zgodnie ze strategią firmy, Fiat Auto Poland zaczął ograniczać swoją działalność w zakresie produkcji komponentów i części, skupiając się na produkcji 
i montażu finalnym samochodów. Proces ten zaowocował sprzedażą zakładów produkujących komponenty. Strategia ta miała miejsce nie tylko w Polsce, ale był to trend w całym światowym przemyśle motoryzacyjnym. Dzięki temu procesowi łatwiej jest wyspecjalizowanym firmom produkującym poszczególne elementy prowadzić rozwój technologiczny, niż jednemu koncernowi. Łatwiej jest również w zakresie znajdowania nabywców. W końcu lat dziewięćdziesiątych proces ten jeszcze bardziej się pogłębił. Fiat Auto Poland, który swoją działalność ograniczył do produkcji silników w Bielsku-Białej i montażu samochodów w Tychach, rozpoczął na terenie tyskiego zakładu rozwijać outsourcing w zakresie podmontażu komponentów na swoich liniach produkcyjnych. Było to kolejnym krokiem zgodnym ze światowym trendem rozwoju lean production na terenie zakładów montażu samochodów. Dotychczasowi główni dostawcy Fiata zostali zobowiązani, poza dotychczas prowadzoną dostawą komponentów, do ich montażu w wytwarzanych samochodach. W ten sposób w Tychach powstało kilka filii najważniejszych dostawców Fiata.

Zakończenie montażu samochodów w Bielsku-Białej było związane ze strategią rozwoju na terenie Bielska produkcji silników, a montażu samochodów w zakładzie w Tychach. W tym celu Fiat zawiązał spółkę jv. z General Motors, która bazowała na bielskim zakładzie Fiata produkującym silniki i skrzynie biegów. Każdy z inwestorów objął po $50 \%$ udziałów w tym przedsięwzięciu. Przedsiębiorstwo wymogło jednocześnie na władzach objęcie nowego zakładu terenem Katowickiej Specjalnej Strefy Ekonomicznej. W ten sposób 1 grudnia 2000 roku powstał w Bielsku zakład Fiat-GM Powertrain.

Oprócz przejęć dawnych zakładów FSM, dochodziło do wykupu także innych podmiotów. Jako przykład warto przytoczyć inwestycję amerykańskiego Delphi, jednego z największych koncernów motoryzacyjnych, który poprzez przejęcie jeleśnickiej filii bielskiej Apeny rozpoczął produkcję wiązek elektrycznych do samochodów. Zakład ten w szczytowym okresie produkcji - w roku 2004, zatrudniał około 2400 pracowników, co stawiało go wśród największych pracodawców tej branży w Polsce.

Dość specyficzną grupę przedsiębiorstw, dostarczających wyroby na potrzeby przemysłu motoryzacyjnego, stanowiły spółdzielnie. Ze względu na statut prawny i duże grono właścicieli, przedsiębiorstwami takimi bardzo trudno zarządzać. Dodatkowo potencjalni kontrahenci działający w sektorze motoryzacyjnym nie mieli zaufania do prowadzenia interesów z tego typu podmiotami. Stąd też w ostatniej dekadzie XX wieku większość z nich wypadła z łańcuchów dostaw. Nieliczna w skali Polski grupa tego typu firm zdołała przekształcić się W spółki prawa handlowego. W przypadku śląskiego przemysłu motoryzacyjnego jedyny taki przypadek stanowią dzisiejsze Zakłady Metalowe Postęp z Zabrza, które przekształciły się w połowie lat dziewięćdziesiątych. Dzięki temu udało im się nie tylko utrzymać się na rynku, ale także zwiększyć produkcję.

Inną grupe przedsiębiorstw stanowią małe podmioty. Część z nich, aby sprostać wymaganiom rynku motoryzacyjnego, musiała przejść proces modernizacji i rozbudowy linii produkcyjnych. Niektóre, aby utrzymać ten profil produkcji, pozyskały inwestorów strategicznych, najczęściej zagranicznych. Przykład takiej firmy stanowi zakład Plastomer w Istebnej, który zawiązał spółkę j.v. z włoskim Lys Fusion, dzięki czemu powstała firma Lys Fusion Poland. Przejęcie to umożliwiło dostawy do Fiata. W późniejszym okresie grupa Lys Fusion, w wyniku procesów globalizacji, została wykupiona przez Koncern ITW - Illinois Tool Works.

Rozmieszczenie łącznych inwestycji w istniejące podmioty przedstawiono na kartodiagramie (ryc. 2). 


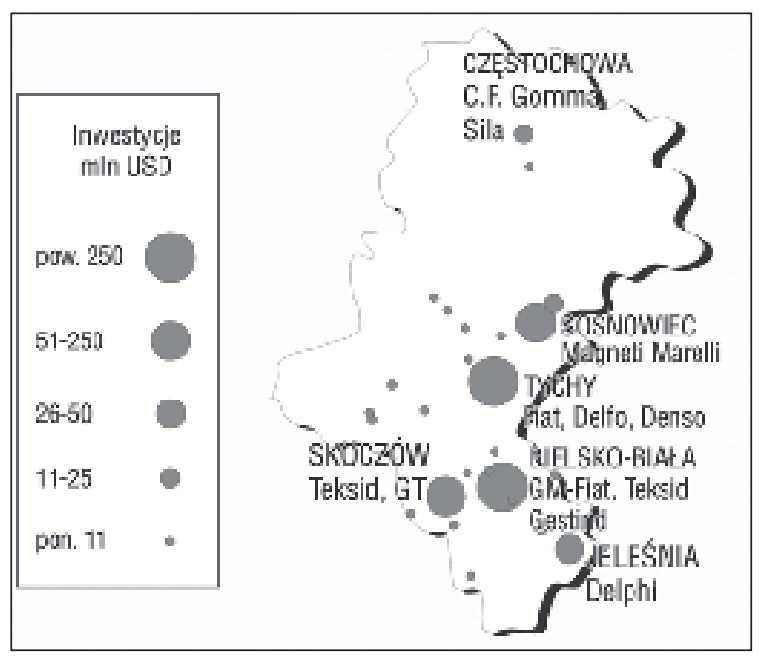

Ryc. 2. Łączne inwestycje w istniejące zakłady w przemyśle motoryzacyjnym po 1990 roku oraz najwięksi inwestorzy

Źródło: Opracowanie własne

W pierwszej połowie lat dziewięćdziesiątych inwestycje w nowe zakłady w przemyśle motoryzacyjnym były relatywnie niewielkie. Te, które powstawały, stanowiły głównie inwestycje typu brownfield. Wynikało to z kilku powodów. Jednym z nich była duża ilość terenów i obiektów poprzemysłowych na terenie województwa śląskiego, dostępnych pod nowe inwestycje. Uruchomienie inwestycji w istniejącej hali jest procesem znacznie szybszym, ze względu na brak konieczności uzyskiwania niezbędnych pozwoleń budowlanych. Największą ilość nowych zakładów tej branży powstałych w tym okresie stanowiły małe i średnie przedsiębiorstwa. W ich przypadku konieczność poniesienia wydatków na budowę hali była zbyt dużym obciążeniem finansowym. W tym okresie na teren województwa śląskiego był bardzo mały napływ dużych inwestorów zagranicznych, którzy inwestując w nowe zakłady, częściej decydują się na budowę własnych zakładów od podstaw niż mali i średni przedsiębiorcy. Rozmieszczenie inwestycji w nowe zakłady przedstawiono na kartodiagramie (ryc. 3).

Duży udział w ilości nowych podmiotów rodzimych firm w początku lat dziewięćdziesiątych wynikał z wprowadzenia zasad wolnego rynku i rozwoju przedsiębiorczości. Większość tych firm swoją produkcję koncentrowało na dostawach dla potrzeb rynku części zamiennych, tzw. aftermarket. Niektórym z nich udało się spełnić wyższe wymagania ze strony odbiorców, będących jednocześnie producentami wyższego rzędu. Wejście w łańcuch dostaw dla przedsiębiorstw motoryzacyjnych dawało mniejszym firmom możliwość uruchomienia wielkoskalowej produkcji. Wymagało to jednak odpowiednich nakładów inwestycyjnych w linie technologiczne i oprzyrządowanie, na co większość z nich nie była w stanie sobie pozwolić.

Najlepszy przykład tego typu firmy stanowi powstała w 1991 roku spółka Pro-Cars w Tychach. Została ona założona przez czterech wspólników, którzy byli wcześniej pracownikami FSM. Możemy mówić więc tutaj o klasycznym procesie spin-off. Powstanie fabryki było związane z planami rozwoju Fiata w Polsce, który zamierzał wdrożyć do produkcji 
nowy model - Cinquecento. Poza tym strategia Fiata zakładała skupienie się na montażu samochodów i silników, a proces produkcji części i podzespołów miał być podzlecany, w czym założyciele Pro-Cars szukali szansy dla swojej firmy. Na początku firma zdecydowała się na produkcję małych elementów tłoczonych, gdyż dla takiej produkcji Fiat starał się szukać lokalnych kooperantów. W miarę rozwoju firmy asortyment produkcji się zwiększał. Rozrastała się też liczba odbiorców. Obecnie najważniejszymi odbiorcami wśród producentów samochodów są, oprócz Fiata, także GM Opel i BMW, a wśród producentów I-tier: Isuzu, Tenneco, Inergy, Delphi, Valeo, Mitsuba, Delfo, Ergom Group, TRW.

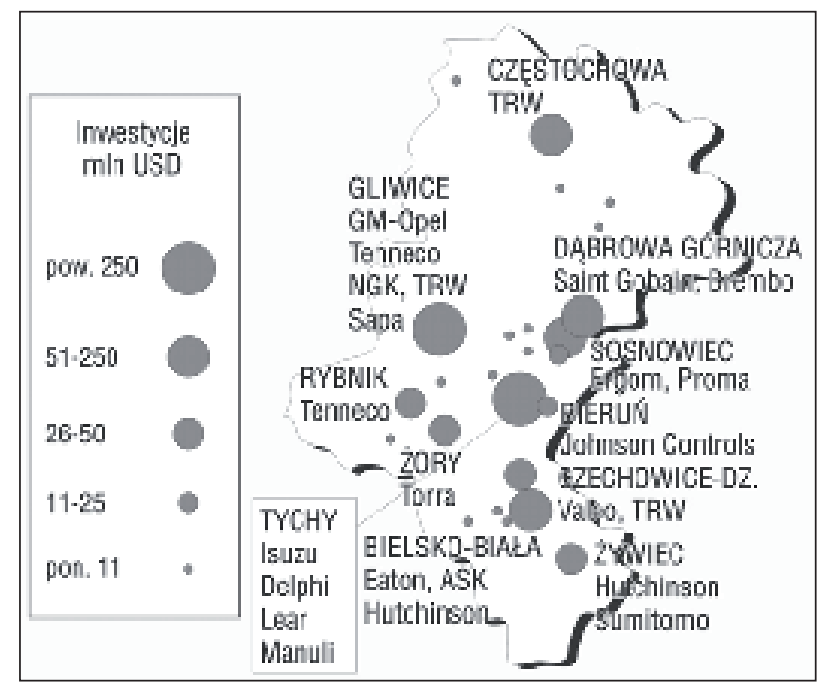

Ryc. 3. Łączne inwestycje w nowe zakłady w przemyśle motoryzacyjnym po 1990 roku oraz najwięksi inwestorzy

Źródło: Opracowanie własne

Wśród zagranicznych inwestorów, szczególnie tych inwestujących w nowe zakłady, przeważały firmy duże i bardzo duże. Jednym z pierwszych tego typu inwestorów był amerykański koncern TRW, należący do grona największych producentów komponentów samochodowych przeznaczonych do pierwszego montażu. W 1990 roku otworzył on swój pierwszy zakład na terenie Częstochowy, tworząc firmę TRW Polska. Od początku działania zajmuje się ona produkcją elementów bezpieczeństwa do samochodów - pasów bezpieczeństwa i poduszek powietrznych. Zakład ten był systematycznie rozbudowywany. W drugiej połowie lat 90. podjęto decyzję o budowie, również na terenie Częstochowy, drugiego zakładu. Długie tradycje produkcyjne, a przez to odpowiednie zaplecze kadrowe, umożliwiły w ostatnim czasie otwarcie w Częstochowie centrum badawczo-rozwojowego systemów bezpieczeństwa koncernu TRW. Na koniec 2004 roku w obydwu zakładach TRW na terenie Częstochowy pracowało około 3250 osób, dzięki czemu obecnie jest to największe przedsiębiorstwo produkcyjne w mieście, a także jedno z największych w branży motoryzacyjnej wśród firm działających w Polsce. W 1996 roku koncern TRW podjął decyzję o budowie kolejnego zakładu produkującego przekładnie kierownicze w Czechowicach-Dziedzicach. Inwestycja ta miała miejsce na części terenu należącego do upadłych wcześniej Zakładów Rowerowych 
Apollo, stanowiących do 1992 roku Zakład nr 8 FSM. Rozwój tego oddziału TRW rozpoczął się od dostaw dla Fiata, ale w późniejszym czasie pozyskano kolejnych odbiorców - Renault i Volkswagena. Obecnie w firmie pracuje około 250 osób, ale plany na najbliższe lata przewidują uruchomienie nowego zakładu i podwojenie liczby pracowników.

Utworzenie w 1996 roku Katowickiej Specjalnej Strefy Ekonomicznej, jako drugiej takiej strefy po Mielcu, znacznie uatrakcyjniło dla nowych inwestorów część obszarów województwa śląskiego. Obszary, które znalazły się w obrębie specjalnych stref ekonomicznych, dawały inwestorom przywileje związane ze zwolnieniami podatkowymi płaconymi w ramach podatków dochodowych od przedsiębiorstw (CIT) i od nieruchomości. Według pierwszych uchwał, SSE były całkowicie zwolnione z podatku CIT na 10 lat, a na kolejne 10 lat podatek ten był redukowany o 50\% w okresie istnienia stref (Dz.U. Nr 123, poz. 600). Do tego dochodziło także zniesienie podatków od nieruchomości płaconych na rzecz gminy. W pierwotnym planie strefą ekonomiczną zamierzano objąć tereny znajdujące się na terenie Sosnowca i Dąbrowy Górniczej (podstrefa sosnowiecko-dąbrowska) oraz Jastrzębia Zdroju i Żor (podstrefa jastrzębio-żorska). Wybór tych miast był spowodowany ich najgorszą sytuacją społeczno-gospodarczą w połowie lat dziewięćdziesiątych, spośród innych ośrodków miejskich obecnego województwa śląskiego. Jednak naciski ze strony lokalnych liderów w Tychach oraz decyzja Opla o utworzeniu fabryki w Gliwicach spowodowały ostatecznie powołanie dwóch kolejnych podsterf - tyskiej i gliwickiej. W latach późniejszych obszar stref był powiększany o kolejne tereny. W chwili obecnej, na skutek nowelizacji Ustawy o specjalnych strefach ekonomicznych, jeżeli jakiś ośrodek pozyska dużego inwestora, Rada Ministrów ma możliwość utworzenia specjalnie dla niego na danej działce obszaru objętego SSE (Dz.U. Nr 117, poz. 1228).

Zarząd Katowickiej Specjalnej Strefy Ekonomicznej oraz niektóre gminy, na terenie których ustanowiono obszary objęte strefą, okazały się też bardzo efektywne w pozyskiwaniu nowych inwestorów. Lata, które upłynęły od początku procesu przemian gospodarczych, spowodowały wypracowanie mechanizmów aktywnego pozyskania inwestorów zagranicznych.

W 1996 roku pozyskano przełomową dla regionu inwestycję w nowy zakład, jaką była fabryka GM Opel w Gliwicach. W ciągu 22 miesięcy zakończono budowę fabryki, składającej się z pełnego kompleksu fabrycznego koniecznego do produkcji samochodów. Oprócz wydziału montażu głównego (montaż samochodów) znajduje się tam tłocznia, wydział karoserii i lakiernia. Uruchomienie produkcji miało miejsce w kwietniu 1998 roku. Najpierw ruszyła produkcja części, a po czterech kolejnych miesiącach zakład opuściła pierwsza Astra Classic. Dwa lata później, w 2000 roku, na terenie zakładu w Gliwicach General Motors uruchomił produkcję microvana Opla Agila. Zaangażowanie się firmy w program offsetowy związany z zakupem myśliwców F-16 od Loockheada Martina dla polskiej armii skutkował dalszym rozwojem zakładu. W kolejnych latach w miejsce wycofanej z produkcji Astry Classic wdrożono do produkcji model Astra II i nową Zafirę. Obecnie prowadzone są dalsze działania w celu uruchomienia produkcji kolejnych modeli samochodów (od sierpnia 2007 roku, w gliwickich zakładach Opla ma rozpocząć się produkcja nowego modelu Opla Astry III). Łączne moce produkcyjne, które fabryka zamierza osiagnąć do końca 2007 roku to wolumen 180 tys. samochodów na rok. Produkcja samochodów Opla w Gliwicach to nie tylko zatrudnienie w GM wynoszące na koniec 2005 roku ponad 3100 pracowników, ale także firmy zajmujące się podmontażem na liniach produkcyjnych (podobnie jak w przypadku Fiata). W gliwickim zakładzie głównym podmontażystą jest firma Sils Center Gliwice, w której zatrudnienie przekroczyło 600 osób. Inne firmy, które zajmują się tą działalnością 
dla Opla, to Plastik Omnium i zakłady Bumar Łabędy, w których łącznie na rzecz Opla pracuje około 400 osób.

Inwestycja Opla była nie tylko przełomowa ze względu na wielkość zatrudnienia w samej fabryce, ale także poprzez jej wpływ na pozyskanie nowych inwestorów. Było to związane $\mathrm{z}$ dwoma procesami. $\mathrm{Z}$ jednej strony mamy do czynienia $\mathrm{z}$ efektem kooperacji, dzięki któremu wokół Opla powstało wiele zakładów dostarczających wyroby do produkcji, a z drugiej strony nowi inwestorzy, niekoniecznie z branży motoryzacyjnej, na pytanie o przyczyny lokalizacji podają wcześniejsze zlokalizowanie się tu fabryki Opla, co świadczy o efekcie naśladownictwa.

Silny efekt kooperacji w przemyśle motoryzacyjnym jest związany ze specyfiką tej branży. Wynika ze skali produkcji, np. zamówienia z jednej fabryki na ponad 2000 foteli samochodowych na dzień, jak również z konieczności dostaw na czas - just-in-time, i to w określonej sekwencji (in-line-sequence) dostarczania na linię. Na to nakłada się system kar za ewentualne opóźnienia w dostawach - wstrzymanie linii produkcyjnej przez dostawcę na czas 1 godziny to koszt od kilkuset tysięcy do kilku milionów złotych. Wszystko to skłania dostawców do otwierania swoich zakładów w pobliżu odbiorcy (producenta samochodów). Jeżeli jest to nieopłacalne z punktu widzenia skali produkcji dostawca tworzy najczęściej dodatkowy magazyn w pobliżu odbiorcy, w którym poza składowaniem towaru prowadzi również jego konfekcjonowanie.

Wśród nowo powstałych przedsiębiorstw motoryzacyjnych znajdujących się w bezpośredniej bliskości GM, są zakłady Plastal, HP Polska, TRW Braking Systems, Fabryka Plastików Gliwice, NGK Ceramics oraz Kirchhoff Assembly. Wszystkie one powstały w głównej części gliwickiej Katowickiej Specjalnej Strefy Ekonomicznej.

Duża liczba nowych zakładów powstała także na terenie tyskiej podstrefy KSSE. Do największych inwestorów należą tu duże międzynarodowe koncerny, takie jak: Isuzu, Lear, Delphi czy Manuli. Zakłady Isuzu były jedną z pierwszych japońskich fabryk zlokalizowanych na terenie Polski. Stanowią one także największą po 1990 roku inwestycję greenfield na terenie Tychów. Największym pracodawcą w tej podstrefie jest amerykański Lear, zatrudniający obecnie ponad 1300 pracowników, produkujący fotele samochodowe przede wszystkim dla zakładów FAP i GM.

Łączny napływ nowych inwestycji do przemysłu motoryzacyjnego województwa śląskiego wyniósł w latach 1990-2005 prawie 5,7 mld USD (ryc. 4). Większość z tych inwestycji stanowiły nakłady w istniejące zakłady, a ich udział w łącznej wartości zainwestowanego kapitału po 1990 roku wyniósł 54,5\%. Wynikało to z dotychczasowego rozwoju tego przemysłu na terenie województwa śląskiego oraz szybkich przekształceń organizacyjnych i własnościowych, którym poddano tę branżę. Dzięki temu zdecydowana większość istniejących tu wcześniej dużych przedsiębiorstw rozwinęła swoją działalność.

Na początku okresu transformacji łączna wielkość zatrudnienia w przedsiębiorstwach przemysłu motoryzacyjnego wynosiła ponad 24,3 tysiąca pracowników. Na koniec roku 2005 zatrudnienie osiagnęło prawie 43,2 tys. osób. Podobnie jak w przypadku napływu inwestycji wielkość zatrudnienia zaczęła przyrastać w drugiej połowie lat dziewięćdziesiątych (ryc. 4). Spadek zatrudnienia w pierwszym okresie był związany ze zwiększeniem wydajności pracy w zakładach istniejących tu przed 1990 rokiem, które weszły w okres transformacji z przerostem zatrudnienia. Dotyczyło to przede wszystkim firm, które wyrosły na bazie dawnych zakładów FSM. Zatrudnienie w tych zakładach było redukowane również w końcu lat dziewięćdziesiątych i na początku pierwszej dekady XXI wieku, ale napływ inwestorów, któ- 
rzy generowali nowe miejsca pracy, znacznie przewyższał te redukcje. Sama tylko fabryka Fiat Auto Poland z siedzibą w Bielsku-Białej i Tychach zmniejszyła zatrudnienie w okresie 1998-2004 z poziomu ponad 9,7 tysiąca pracowników do niespełna 3,7 tysiąca.

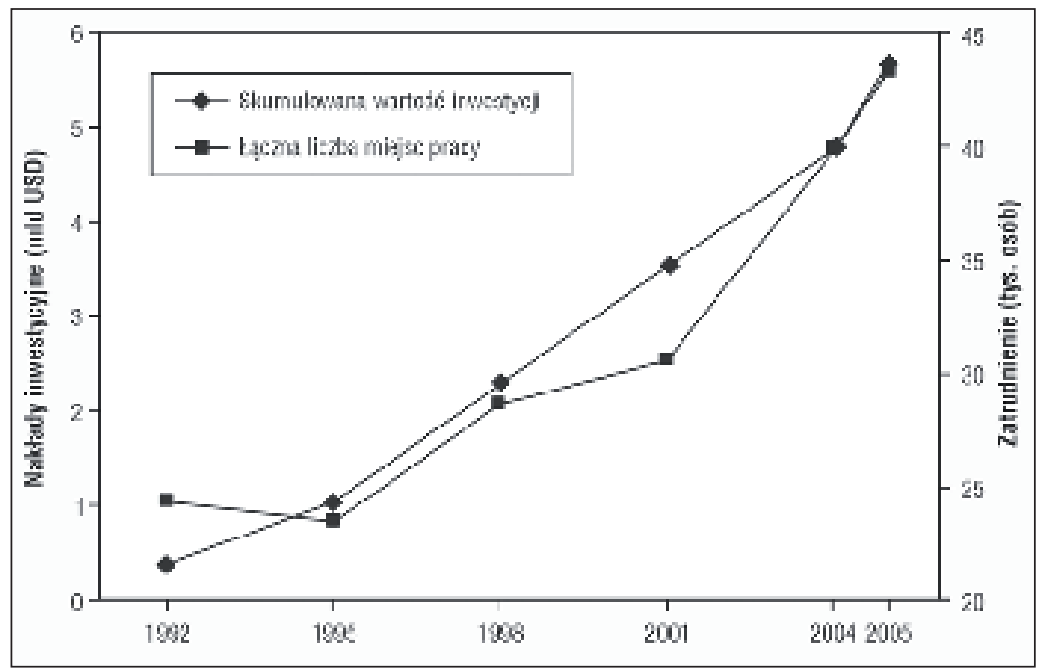

Ryc. 4. Liczba miejsc pracy oraz skumulowana wartość inwestycji w przemyśle motoryzacyjnym województwa śląskiego po 1990 roku

Źródło: Opracowanie własne

\section{OBECNA STRUKTURA I ROZMIESZCZENIE PRZEDSIĘBIORSTW \\ PRZEMYSŁU MOTORYZACYJNEGO}

Decydujący wpływ na ogólny obraz rozmieszczenia przedsiębiorstw motoryzacyjnych mają inwestycje w duże i bardzo duże zakłady. Firmy, które zainwestowały ponad $25 \mathrm{mln}$ USD, skupiły łącznie 89,5\% zainwestowanego tutaj kapitału, a udział tych, których wartość inwestycji przekroczyła $10 \mathrm{mln}$ USD, stanowi ponad 95\%. Największymi inwestorami są przedsiębiorstwa produkujące samochody (FAP i GMMP) oraz producenci jednostek napędowych (GM-Fiat Powertrain i Isuzu). Kolejną grupę dużych inwestorów stanowią zlokalizowani tu producenci skomplikowanych urządzeń dostarczanych bezpośrednio do montażu w zakładach samochodowych (np. kolumny kierownicze, półosie napędowe - Delphi; systemy oświetlenia - Magneti Marelli; układy wydechowe - Tenneco; amortyzatory i zawieszenia - Tenneco; układy hamulcowe - TRW) oraz firmy produkujące wyroby metalowe (m.in. odlewnie - Teksid Iron, Teksid Aluminium, Brembo; zawory do silników - Eaton), ceramiczne (NGK Ceramics) i szklane (Saint Gobain).

Nieco mniejszy jest udział największych firm (powyżej 250 zatrudnionych) w łącznym zatrudnieniu generowanym w województwie śląskim przez tę branżę, wynosi niespełna $85 \%$. 
Do największych pracodawców zatrudniających ponad 1000 osób należą, obok wymienionych powyżej producentów samochodów i silników, przedsiębiorstwa działające w branżach pracochłonnych. Jako przykład można wymienić firmę TRW Polska, która zatrudniając około 3500 pracowników należy do największych pracodawców w polskim przemyśle motoryzacyjnym. Zajmuje się ona szyciem pasów bezpieczeństwa i poduszek powietrznych. Inny przykład podobnego przedsiębiorstwa stanowią tyskie zakłady Lear zatrudniające ponad 1300 osób. Zajmują się one produkcją foteli, w której duży udział stanowi pracochłonne szycie materiałów. Drugi zakład o tym samym profilu zostanie otwarty w tym roku przez koncern Johnson Controls. Planowane zatrudnienie ma także dochodzić do 1000 osób. Kolejnym przykładem branży pracochłonnej jest produkcja wiązek elektrycznych. Zatrudnienie w tego typu firmach na terenie województwa śląskiego dochodzi do 2400 pracowników w przypadku jeleśnickiego oddziału Delphi. Wśród innych producentów tej branży, którzy ulokowali tutaj swoją działalność, są koncerny Valeo, Sumitomo i Cablelettra.

$\mathrm{Na}$ przeciwnym biegunie znajdują się małe przedsiębiorstwa (poniżej 50 zatrudnionych). Na terenie województwa śląskiego skupiają one ułamek nakładów i zatrudnienia w tej branży. Zajmują się głównie produkcją na rynek wtórny, tzw. aftermarket, rozprowadzając swoje wyroby poprzez hurtownie motoryzacyjne i stacje obsługi. Ich wejście w łańcuchy dostaw dla motoryzacji jest praktycznie niemożliwe ze względu na szereg wymagań przed nimi stawianych. Samo zdobycie koniecznych certyfikatów jakości (obecnie ISO TS 16949), umożliwiające podjęcie rozmów o współpracy, kosztuje od 60 do 100 tys. PLN, W zależności od rodzaju firmy (Konieczny 2006, Zadorożny 2006). W przypadku starania się o kontrakt, konieczne jest wyprodukowanie prototypu i narzędzi do seryjnej produkcji. Z zależności od rodzaju i stopnia skomplikowania komponentu wiąże się to z wydatkiem na poziomie od kilkudziesięciu tysięcy do kilku milionów PLN. Poza koniecznością wyłożenia takiego kapitału trzeba jeszcze dysponować odpowiednią komórką badawczo-rozwojową, która będzie w stanie opracować dany element. Samo podjęcie współpracy wiąże się jeszcze z koniecznością ubezpieczenia własnej produkcji na wypadek wady produktu ujawnionej w okresie eksploatacji samochodu. Dodatkowy problem przy staraniu się o podjęcie współpracy stanowi presja ze strony firm znajdujących się na górze łańcucha dostaw, na współpracę z dużymi podmiotami, które będą w stanie obsłużyć wiele kontraktów. Dla przykładu koncern Delphi, którego roczna wartość dostaw przekracza 14 mld USD, stara się ograniczyć liczbę dostawców do poziomu 1000 firm. Daje to średnią wartość 14 mln USD dla dostaw od danego podmiotu. Pokazuje to skalę oczekiwanych przychodów. Presja ta obecnie powoduje, że wiele małych podmiotów wypada z tego rynku, a te, które się na nim utrzymują spadają na niższy poziom w łańcuchu dostaw.

W strukturze śląskich firm motoryzacyjnych dominują przedsiębiorstwa o kapitale zagranicznym. W przypadku liczby podmiotów przewaga ta jest niewielka, natomiast wskaźnik wielkości zatrudnienia i wartości inwestycji pokazuje zdecydowaną przewagę tych firm. Uwidacznia to wyraźną różnicę wielkości pomiędzy przedsiębiorstwami o kapitale rodzimym i zagranicznym. Te pierwsze są przedsiębiorstwami znacznie mniejszymi. Przekłada się to na niską pozycję tych firm w łańcuchach dostaw. Najczęściej funkcjonują one jako dostawcy na rynek wtórny lub też znajdują się na niższych szczeblach w łańcuchu dostaw - dostawcy II i niższego rzędu. Firm z kapitałem polskim dostarczających komponenty bezpośrednio do producentów samochodów jest zaledwie kilku.

Rozmieszczenie przemysłu motoryzacyjnego wykazuje tendencje do tworzenia skupień przestrzennych nazywanych gronami lub clustrami przedsiębiorstw. W przypadku tej branży 
powstają one na skutek więzi kooperacyjnych tworzonych przez firmy znajdujące się w górnych częściach łańcuchów dostaw. Tendencję tę pokazuje m.in. skala rozwoju tego przemysłu w trzech ośrodkach - Tychach, Gliwicach i Bielsku-Białej (ryc. 5), które do końca 2005 roku skupiły najwięcej łącznych nakładów inwestycyjnych po 1990 roku - ponad 85\% oraz miały najwyższy poziom zatrudnienia - ponad 50\% w skali całego województwa. Rozwój przedsiębiorstw branży motoryzacyjnej $\mathrm{w}$ tych miastach był oparty na produkcji samochodów. Ten rodzaj produkcji jest bardzo kapitałochłonny oraz wykazuje zapotrzebowanie na dużą liczbę pracowników. Dodatkowo, poprzez efekty zaopatrzeniowe, powoduje tworzenie się skupisk kooperantów w najbliższym możliwym otoczeniu fabryk.

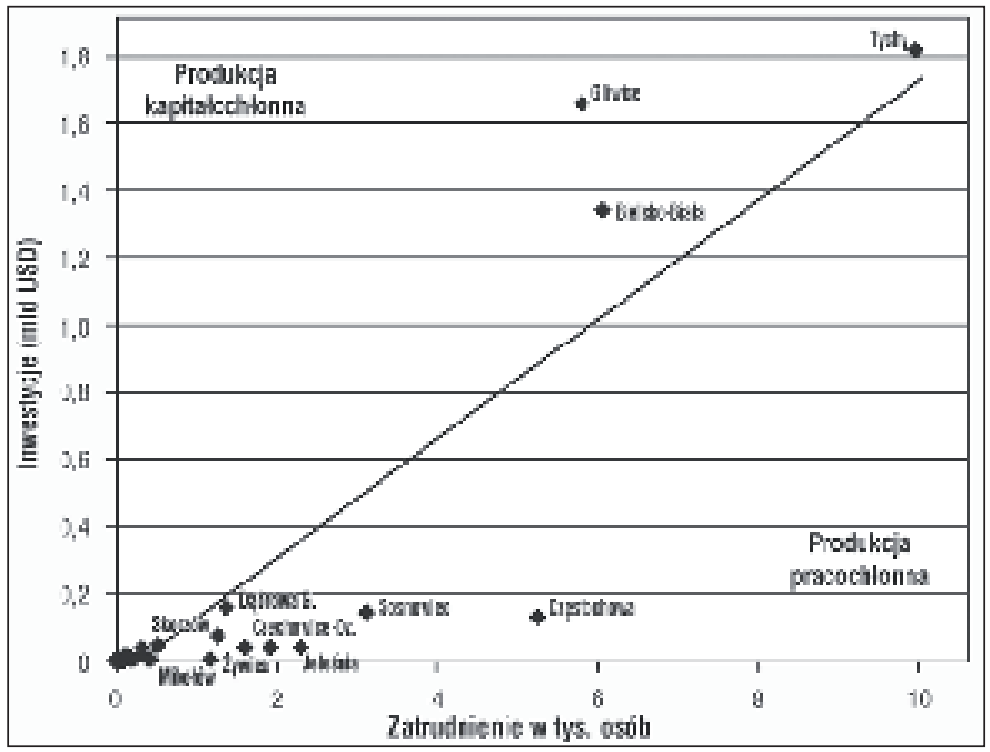

Ryc. 5. Wielkość zatrudnienia w 2005 roku i łączne nakłady inwestycyjne w latach 1990-2005 w przemyśle motoryzacyjnym według miejscowości

Źródło: Opracowanie własne

Kolejnymi ważnymi ośrodkami pod względem napływu inwestycji do tej branży przemysłu są: Częstochowa, Sosnowiec i Dąbrowa Górnicza (ryc. 5). Miasta te cechują się podobną wartością pozyskanych inwestycji w tej branży, przy bardzo dużym zróżnicowaniu wielkości zatrudnienia. Wynika to ze specyfiki najważniejszych zakładów działających na terenie tych miast. W przypadku Częstochowy, koncern TRW - przy relatywnie niskich nakładach inwestycyjnych - uruchomił tu dwa zakłady szycia pasów bezpieczeństwa i poduszek powietrznych, w których zatrudnienie znalazło prawie 3,5 tys. pracowników. Zakłady te, znajdujące się w łańcuchu dostaw na poziomie I-rzędu, wytworzyły mniejsze powiązania kooperacyjne niż w przypadku producentów samochodów, niemniej zlokalizowały się przy nich zakłady kooperujące w zakresie szycia pasów bezpieczeństwa.

Następną ważną pod względem wielkości zatrudnienia grupę ośrodków stanowią: Jeleśnia, Czechowice-Dziedzice, Żywiec i Mikołów, w których zlokalizowały się firmy produkujące wiązki elektryczne do samochodów. Produkcja ta należy do najbardziej pracochłonnych branż w ramach przemysłu motoryzacyjnego. Ze względu na dużą pracochłon- 
ność, łatwość transportu gotowych wiązek oraz niewielkie nakłady inwestycyjne, konieczne do uruchomienia produkcji, najłatwiej podlega ona także procesowi relokacji. Należy to mieć na uwadze, gdyż obecnie wysoka pozycja tych miejscowości może ulec osłabieniu, a nawet ośrodki te mogą zniknąć z mapy motoryzacyjnej w ciągu najbliższych lat, w przypadku zamknięcia tych zakładów. Na terenie Jeleśni i Mikołowa są to bowiem jedyne liczące się firmy motoryzacyjne. Proces ten może spowodować jednocześnie duży wzrost bezrobocia na terenie tych ośrodków.

\section{SKALA ODDZIAŁYWANIA PRZEMYSŁU MOTORYZACYJNEGO}

\section{NA REGION WOJEWÓDZTWA ŚLĄSKIEGO}

Dotychczasowy rozwój przemysłu motoryzacyjnego na terenie województwa śląskiego ukazuje jego duży wpływ na otoczenie lokalne i regionalne. Dotyczy to zarówno okresu socjalistycznego, jak i - w jeszcze większym stopniu - gospodarki wolnorynkowej. Nowe inwestycje w zakłady produkujące samochody zawsze wiązały się z napływem nowych technologii do wielu branż przemysłu. Poza tym przemysł ten generuje także duże zatrudnienie zarówno w samych firmach motoryzacyjnych, jak i w ich otoczeniu. Jest to wynikiem znacznej wielkości produkcji, a co za tym idzie dużego zapotrzebowania na dostawy surowców i półwyrobów oraz na usługi.

Do dziedzin przemysłu, które odnoszą największe korzyści w wyniku rozwoju motoryzacji, należą przede wszystkim hutnictwo stali i metali lekkich, przetwórstwo i produkcja tworzyw sztucznych i wyrobów gumowych, przetwórstwo metali oraz produkcja wyrobów elektrycznych i elektronicznych. Dzięki zastosowaniu modelu efektów mnożnikowych (Wiedermann 2007) w przypadku przemysłu motoryzacyjnego województwa śląskiego oszacowano, że we wszystkich tu zlokalizowanych firmach świadczących dostawy wyrobów do dalszego przetworzenia w zakładach motoryzacyjnych, pracuje na terenie tego województwa około 670 osób. Te firmy generują kolejne miejsca pracy w zaopatrzeniu oraz poprzez efekty dochodowe swoich pracowników, co daję łączną ilość pracujących dzięki popytowi na materiały produkcyjne wynoszącą ok. 1000 osób.

W przypadku usług firmy motoryzacyjne generują dużą liczbę miejsc pracy przede wszystkim w transporcie, serwisowaniu urządzeń i sprzątaniu obiektów, produkcji narzędzi, ochronie oraz usługach wyższego rzędu, w tym najważniejsze są firmy projektowe i zakłady badawczo-rozwojowe. Obliczono, że przemysł motoryzacyjny skupiony na terenie województwa śląskiego daje przynajmniej 4950 miejsc pracy w firmach zlokalizowanych na terenie tego województwa, które świadczą na jego rzecz powyższe usługi. W tym przypadku firmy te korzystają także z zaopatrzenia oraz - poprzez płace pracowników - generują dodatkowe miejsca pracy w handlu i usługach świadczonych na ich rzecz. Łącznie daje to przynajmniej 6440 miejsc pracy na terenie województwa śląskiego, które wynikają z zapotrzebowania na usługi dla firm motoryzacyjnych.

Poza efektami mnożnikowymi na regionalnym rynku pracy, wynikającymi z zaopatrzenia przedsiębiorstw, firmy te generują zatrudnienie w handlu i usługach poprzez płace przekazywane pracownikom. W tym przypadku ilość wygenerowanych miejsc pracy wynosi około 4980, przy czym miejsca pracy w handlu i usługach są związane z zaopatrzeniem tych firm, co daje dodatkowo ponad 630 miejsc pracy. 
Zsumowanie składowych wartości daje łączny szacunek wszystkich miejsc pracy powstałych w gospodarce regionalnej w wyniku rozwoju tutejszego przemysłu motoryzacyjnego wynoszący około 13060 miejsc pracy. Ze względu na przyjęte założenia dotyczące m.in. współczynników domknięcia i in. możemy wartość tę zaokrąglić w dół do pełnego tysiąca osób, dzięki czemu możemy powiedzieć, że rozwój przemysłu motoryzacyjnego od swego początku do końca 2005 roku spowodował powstanie przynajmniej 13 tys. dodatkowych miejsc pracy na terenie województwa śląskiego.

Dla dalszego rozwoju tego przemysłu kluczową kwestią jest rozwój zakładów zajmujących się montażem samochodów. To właśnie one stoją u podstaw kształtowania się sieci powiązań kooperacyjnych wynikających z największego zapotrzebowania na dostawy. Dzięki tym firmom następuje także największy transfer wiedzy i technologii do innych dziedzin przemysłu.

Zarówno w przypadku FAP jak i GMMP zakłady te są najlepszymi oddziałami w ramach swoich koncernów. Dotyczy to zarówno wydajności pracy, jakości wyrobów, jak i wyników finansowych. Te przesłanki powoduja, że powstające nowe projekty samochodów często trafiają do dalszej produkcji właśnie w polskich zakładach. W przypadku gliwickiego GM jest to pozyskany niedawno nowy model Zafiry, natomiast FAP po sukcesie produkcyjnym nowego modelu Pandy przymierza się do uruchomienia produkcji nowego modelu Fiata 500 oraz wspólnie z Fordem uruchamia w Tychach produkcję nowego modelu Forda Ka. W najbliższym okresie można się więc spodziewać wzrostu wielkości produkcji w obu zakładach, co przełoży się także na wzrost zapotrzebowania na dostawy, przyczyniając się do dalszego rozwijania zakładów kooperantów.

W przypadku większości dostawców sytuacja firm jest podobna do producentów samochodów. Dobre wyniki odbiorców i duże zapotrzebowanie na wyroby przekłada się na wzrost zamówień. Sprzyja to osiaganiu lepszych wyników, a jest to najważniejszy czynnik przy decyzjach central koncernów o przyznawaniu nowych projektów. W ten sposób tutejsi kooperanci GM i Fiata coraz częściej pozyskują także nowe działalności wykonywane dla podmiotów zlokalizowanych nie tylko poza granicami województwa, ale także kraju.

\section{Literatura}

Bagdziński S., Maik W., 1994, Determinants of regional and spatial policy in the period of system transformation, [w:] R. Domański, E. Judge (red.), Changes in the regional economy in the period of system transformation, Warszawa, 55-69.

Dicken P., Forsgreen M., Malmberg A., 1994, Local embeddedness and transnational corporations, [in:] A. Amin, N. Thrift (eds.), Globalisation, institutions and regional development in Europe, Oxford, 23-45.

Dicken P., Malmberg A., 2001, Firms in territories: a relational perspective, „Economic Geography” $77,345-363$.

Domański B., 2001, Kapitat zagraniczny w przemyśle Polski, Kraków.

Domański B., 2004, Local and regional embededdness of foreign industrial investors in Poland, „Prace Geograficzne", IGiGP UJ, 114, Kraków, 37-54.

Domański B., Gwosdz K. (red.), 2005, Dziesięć lat doświadczeń pierwszej polskiej specjalnej strefy ekonomicznej. Mielec 1995-2005, IGiGP UJ, ARP o. Mielec, Kraków, 89-132.

Domański B., Gwosdz K., Huculak M., Wiedermann K., 2005, Oddziaływanie SSE Euro-Park Mielec na otoczenie lokalne. Powiqzania firm i efekty mnożnikowe, [w:] Dziesięć lat doświadczeń pierw- 
szej polskiej specjalnej strefy ekonomicznej, Mielec 1995-2005, Kraków

Grabher G., 1994, The disembedded regional economy: the transformation of East German industrial complexes into western enclaves, [in:] A. Amin, N. Thrift (eds.), Globalization, institutions and regional development in Europe, Oxford, 177-195.

Hardy J., 1998, Cathedrals in the desert? Transnationals, corporate strategy and locality in Wrockaw, „Reg. Stud.”, 32, 7, 639-652.

Hayter R., Watts H.D., 1983, The geography of enterprise: a reappraisal, „Progress in Human Geogr.”, 7, $157-181$.

Hurley N.P., 1959, The automotive industry, A study in industrial location, „Land Economics”, 35, 1-14. Industrial Statistic Database, 2001, UNIDO.

Konieczny M., 2006, „Grupowe wdrożenia ISO/TS 16949:2002 - szansa na rozwiązanie problemu współpracy OEM z poddostawcami niższego rzędu”, PIM Consulting, Referat wygłoszony na konferencji Autoevent Poznań.

Kukliński A., 1991, Restrukturyzacja regionów jako problem wspótpracy europejskiej, [w:] A. Kukliński, B. Jałowiecki (red.), Restrukturyzacja regionów jako problem wspótpracy europejskiej, t. 1, Stud. Regionalne i Lokalne, 1 (34), Warszawa, 319-329.

Riley R.C., 1973, Industrial Geography, London

Sadler D., 1998, Changing Inter-firm Relations in the European Automotive Industry: Increased Dependance or Enhanced Autonomy for Competents Producers?, European Urban and Regional Studies, (4) 5, 317-328.

Scott A.J., 1988, New industrial space: flexible production and regional economic development in the USA and Western Europe, London.

Scott A.J., Storper M., 1987, High technology industry and regional development: a theoretical critique and reconstruction, „International Soc. Science Journal”, 112, 215-232.

Sobala-Gwosdz A., 2000, The influence of large manufacturing firmson the local development of Jarostaw in the 1990s, [w:] T. Marszał (red.), Local economy and urban development of Poland, Łódź, 62-69.

Stryjakiewicz T. (red.), 2004, Wpływ inwestorów zagranicznych na rozwój regionalny i lokalny, Poznań.

Ustawa z dnia 20 października 1994 roku o specjalnych strefach ekonomicznych (Dz.U. Nr 123, poz. 600)

Ustawa z dnia 16 listopada 2000 roku o zmianie ustawy o specjalnych strefach ekonomicznych oraz o zmianie niektórych ustaw (Dz.U. Nr 117, poz. 1228).

Watts H.D., 1987, Industrial geography, New York.

Wiedermann K., 2007, Regionalne efekty mnożnikowe rozwoju przemystu motoryzacyjnego $w$ aktywizacji gospodarczej województwa ślaskiego, [w:] Z. Zioło i T. Rachwał (red.), Rola przedsiębiorczości w aktywizacji gospodarczej, Przedsiębiorczość - Edukacja t. III, Kraków (w druku)

Zadorożny R., 2006, „Znaczenie specyficznych wymagań klientów dla certyfikacji wg ISO/TS 16949:2002, DERKA”, Referat wygłoszony na konferencji Autoevent Poznań.

\section{Factors and effects of development of car-manufactures in the area of the Silesian Voivodeship}

The article on factors and effects of development of car-manufactures in the area of the Silesian Voivodeship consists of an introduction, three main units and conclusions. The first chapter describes the development of this branch since the beginnings to the end of 2005. The functioning of automotive firms till the transformation period in the end of 1980s is shown very briefly. The 1990-2005 processes of location of new investments is divided in two different periods. The first one is characterized 
mainly by acquisitions and brownfields (e.g. Fiat). In the second period the share of greenfield was much bigger. The main reason for such processes was the establishment of Katowice Special Economic Zone and the new production plant of GM Opel in Gliwice in 1996. The next unit of this paper shows contemporary distribution of car- and assembly manufacturers. The last part contains an account of the influence of automotive firms on the local and regional economy, which is counted by the number of workplaces established as a result of multiplier effects of the development of car- manufactures. The estimated amount of new workplaces in the surroundings of automotive firms is at least 13 thousand. 